\title{
Estimate of respiration rate and physicochemical changes of fresh-cut apples stored under different temperatures
}

\author{
Estimativa da taxa de respiração e das mudanças físico-químicas de maçãs \\ minimamente processadas e estocadas sob diferentes temperaturas
}

\author{
Cristiane FAGUNDES ${ }^{1}$, Bruno Augusto Mattar CARCIOFI ${ }^{1}$, Alcilene Rodrigues MONTEIRO ${ }^{1 \star}$
}

\begin{abstract}
In this study, the influence of storage temperature and passive modified packaging (PMP) on the respiration rate and physicochemical properties of fresh-cut Gala apples (Malus domestica B.) was investigated. The samples were packed in flexible multilayer bags and stored at $2{ }^{\circ} \mathrm{C}, 5^{\circ} \mathrm{C}$, and $7{ }^{\circ} \mathrm{C}$ for eleven days. Respiration rate as a function of $\mathrm{CO}_{2}$ and $\mathrm{O}_{2}$ concentrations was determined using gas chromatography. The inhibition parameters were estimated using a mathematical model based on Michaelis-Menten equation. The following physicochemical properties were evaluated: total soluble solids, $\mathrm{pH}$, titratable acidity, and reducing sugars. At $2^{\circ} \mathrm{C}$, the maximum respiration rate was observed after 150 hours. At $5{ }^{\circ} \mathrm{C}$ and $7{ }^{\circ} \mathrm{C}$ the maximum respiration rates were observed after 100 and 50 hours of storage, respectively. The inhibition model results obtained showed a clear effect of $\mathrm{CO}_{2}$ on $\mathrm{O}_{2}$ consumption. The soluble solids decreased, although not significantly, during storage at the three temperatures studied. Reducing sugars and titratable acidity decreased during storage and the $\mathrm{pH}$ increased. These results indicate that the respiration rate influenced the physicochemical properties.

Keywords: fresh-cut; apples; respiration rate.
\end{abstract}

\section{Resumo}

Neste estudo, a influência da temperatura de armazenamento e da embalagem com atmosfera modificada passiva (AMP) na taxa respiratória e nas propriedades físico-químicas de maçãs da variedade Gala (Malus domestica, B.) minimamente processadas foi investigada. As amostras foram acondicionadas em embalagens flexíveis e armazenados a $2{ }^{\circ} \mathrm{C}, 5{ }^{\circ} \mathrm{C}$ e $7{ }^{\circ} \mathrm{C}$, durante 11 dias. A taxa de respiração foi gerada para diferentes concentrações de $\mathrm{O}_{2} \mathrm{e} \mathrm{CO}_{2}$, obtidas por cromatografia gasosa. Os parâmetros de inibição foram estimados por um modelo matemático baseado na equação de Michaelis-Menten. Foram avaliadas as seguintes propriedades físico-químicas: sólidos solúveis totais, pH, acidez titulável e açúcares redutores. A $2^{\circ} \mathrm{C}$, a taxa de respiração máxima foi observada após 150 horas. A $5^{\circ} \mathrm{C}$ e $7{ }^{\circ} \mathrm{C}$, a taxa de respiração máxima foi observada após 100 horas e 50 horas de armazenamento, respectivamente. Os resultados obtidos para os modelos de ininbição mostraram um claro efeito do $\mathrm{CO}_{2}$ no consumo de $\mathrm{O}_{2}$. O teor de sólidos solúveis diminuíram, sem um efeito significativo durante o armazenamento nas três temperaturas. Açúcares redutores e acidez titulável diminuíram, e o pH aumentou durante o armazenamento. Os resultados mostraram que as propriedades físico-químicas foram influenciadas pela taxa de respiração do produto.

Palavras-chave: processamento mínimo; maçã; taxa respiratória.

\section{Introduction}

In recent years, the demand for fresh-cut fruits has significantly increased due to the advantages offered by such products to consumers such as freshness, convenience, and low caloric content. Besides, consumers want safe and natural products without additives such as preservatives and humectants. However, it is difficult to preserve the quality of fresh-cut fruits (WU; ZHANG; WANG, 2012). Fresh-cut products are highly perishable due to the disruption of tissue and cell integrity, with a concomitant increase in the enzymatic, respiratory and microbiological activity, which reduce the shelflife of these products (OLUSOLA, 2002). To extend the shelf life of fresh-cut produce without compromising nutritional quality, many methods have been proposed including low temperature, modified atmosphere packaging (MAP), antibrowning dipping, and edible coatings (ALBANESE; CINQUANTA; DI MATTEO, 2007).

Respiration is the main process of deterioration of fresh produce, and it can be considered a metabolic process aiming at the oxidative breakage of organic substrates into simple molecules such as $\mathrm{CO}_{2}$ and $\mathrm{H}_{2} \mathrm{O}$ with the production of energy (FONSECA; OLIVEIRA; BRECHT, 2002). Respiration rate depends on the storage environment, particularly regarding its gaseous composition, relative humidity, and temperature. Decreases in $\mathrm{O}_{2}$ concentration as well as increases in $\mathrm{CO}_{2}$ concentration lead to a decrease, up to certain limits, in the respiration rate of fruits and vegetables (SALTVEIT, 2003; ROCCULI et al., 2006). This is one of the main factors that

Received 12/12/2011

Accepted 18/10/2012 (005542)

${ }^{1}$ Laboratório de Propriedades Físicas, Departamento de Engenharia Química e Engenharia de Alimentos, Universidade Federal de Santa Catarina - UFSC, Campus Trindade, CP 476, CEP 88040-900, Florianópolis, SC, Brasil, e-mail: alcilene@enq.ufsc.br

${ }^{*}$ Corresponding author 
accelerate the loss of quality of fresh-cut products since respiratory substrates such as sugars and acids are consumed in this process. High respiration rates indicate metabolic activity of plant tissues, thus becoming a guide for the shelf life of products (CHITARRA; CHITARRA, 2005).

A respiration model, based on enzyme kinetics, was proposed by Lee, Song and Yam (1996) to predict respiration rates of fresh produce as a function of $\mathrm{O}_{2}$ and $\mathrm{CO}_{2}$ concentrations. According to Yang and Chinnan (1988), the principles of enzyme kinetics might be appropriate for modeling the respiration rate of fresh produce. These authors suggested that a MichaelisMenten-type equation can be used considering the following rationale: respiration in fresh produce is possibly governed by an enzymatic reaction catalyzed by enzymes and regulated through inhibition. High $\mathrm{CO}_{2}$ concentrations can reduce the $\mathrm{O}_{2}$ consumption rate of a number of fruits and vegetables. This reduction can be modeled by three types of inhibition in an enzyme kinetics model: competitive; uncompetitive; and noncompetitive type. Although the description of the relationship between $\mathrm{O}_{2}$ concentrations and $\mathrm{O}_{2}$ consumption rates by Michaelis-Menten kinetics is a simplification based on a single enzymatic reaction instead of all enzymes involved, the results showed good fit to the experimental data (PEPPELENBOS; LEVEN, 1996).

Modified atmosphere packaging (MAP) is one of the most important food preservation methods that maintain the natural quality and extend the storage life of fruits and vegetables (JAYAS; JEYAMKONDAN, 2002; MARTÍNEZ-FERRER et al., 2002). Changes in the carbon dioxide and oxygen concentrations in the packages could help maintain freshness and visual appearance of fresh-cut produce by reducing respiration and/ or physiological deterioration during storage (KADER, 1986; ROCHA; BARREIRO; MORAIS, 2004). Soliva-fortuny, Elezmartinez and Martin-Belleso (2004) and Pareira et al. (2004) used MAP to extend the shelf life of minimally processed fruits and vegetables. The modified atmosphere, along with low temperatures, effectively delayed the respiration rate and senescence of fresh-cut vegetables (SOLIVA-FORTUNY et al., 2005).

The main goal of this research was to study the effects of passive modified atmosphere packaging (MAP) and temperature on the respiration rate, physicochemical changes, and microbial growth of fresh-cut apples during storage.

\section{Materials and methods}

\subsection{Raw material}

The apples (Malus domestica, Borkh) Cv Gala used in this study were grown at POMERANA farm located in São Joaquim, state of Santa Catarina, Brazil. They were harvested in January of 2009 and placed into cold storage at $12{ }^{\circ} \mathrm{C}$ under modified atmosphere. The Gala cultivar was chosen because of its high consumption in the country.

\subsection{Processing}

Selected apples of uniform size, color, and physical integrity were washed in running water and sanitized in a $100 \mathrm{ppm}$ sodium hypochlorite solution for 20 minutes. Next, the apples were manually cut in slices of approximately $0.5 \mathrm{~cm}$ of thickness. The apple slices were treated in solutions (antibrowning agents) of $2.0 \%$ of ascorbic acid (AA) and $1.0 \%$ of $\mathrm{CaCl}_{2}$ for 5 minutes, and the excess of water was drained by centrifugation for 40 seconds. The experiments were performed at room temperature $\left(15^{\circ} \mathrm{C}\right)$. Storage samples: $200 \mathrm{~g}$ of apple slices were manually packed in multilayer (biaxial oriented polypropylene - BOPP and low density polyethylene - LDPE) bags and sealed using a plastic bag sealer (Sulpack, Brazil). The packages were immersed in water to evaluate sealing efficiency. The bags were stored in chambers with controlled temperature (Expectron Tecnologia Industrial Ltda model ECB-EX. Brazil), $2{ }^{\circ} \mathrm{C}, 5^{\circ} \mathrm{C}$, and $7{ }^{\circ} \mathrm{C}$. During the storage period, the relative humidity of the atmosphere ranged from $74 \%$ to $78 \%$. All experiments were carried out in triplicate.

\subsection{Gas exchange measurements in the packages}

The experiments were conducted by storing apple slices inside seventy-two permeable packages. The concentration of gas inside the bags was monitored for 190 hours. The analyses were performed triplicate in each bag for each different temperature value tested. The gas samples were taken with a $1 \mu \mathrm{L}$-syringe through rubber septum was attached to the outside of the bags. The concentrations of $\mathrm{CO}_{2}$ and $\mathrm{O}_{2}$ were determined by gas chromatography using a CG 35 gas chromatograph model with a thermal conductivity detector, a molecular sieve, and a Porapak Q column with helium as the stripping gas at a flow rate of $30 \mathrm{~mL} / \mathrm{min}$. The following conditions were used: detector temperature $130^{\circ} \mathrm{C}$; the column temperature $50^{\circ} \mathrm{C}$; and current $240 \mathrm{~mA}$. The retention time for $\mathrm{CO}_{2}$ was two minutes and for $\mathrm{O}_{2}$ one minute. The standard gas samples were collected at a pressure of $1 \mathrm{~atm}$. The experimental data of the $\mathrm{O}_{2}$ and $\mathrm{CO}_{2}$ concentration versus time was fitted to Equations 1 and 2 (LEE; SONG; YAM, 1996) using a nonlinear regression function in Matlab $^{\circledR}$ software (Mathworks Inc., USA).

$$
\begin{aligned}
& {\left[O_{2}\right]=21-A_{1}\left[1-e^{-\left(B_{1}+C_{1} t\right)^{D_{1}}}\right]} \\
& {\left[\mathrm{CO}_{2}\right]=A_{2}\left[1-e^{-\left(B_{2}+C_{2} t\right)^{D_{2}}}\right]}
\end{aligned}
$$

where $A_{1}, A_{2}, B_{1}, B_{2}, C_{1}, C_{2}, D_{1}$, and $D_{2}$ are the fitting parameters.

\subsection{Respiration rate}

The respiration rates of $\mathrm{O}_{2}$ consumption and $\mathrm{CO}_{2}$ evolution were obtained from a $\mathrm{CO}_{2}$ and $\mathrm{O}_{2}$ concentrate. A computer program was developed using the MATLAB ${ }^{\bullet}$ software (Mathworks Inc., USA) to determine the respiration rates using the model proposed by Lee, Song, and Yam (1996), according to Equations 3 and 4. 
$r_{O 2}=-\left(\frac{d\left[O_{2}\right]}{100 d t}\right)\left(\frac{V}{m}\right)+\left(\frac{S P_{O_{2}}\left(0.21-\frac{O_{2}}{100}\right) p}{m L}\right)$

$r_{\mathrm{CO} 2}=+\left(\frac{d\left[\mathrm{CO}_{2}\right]}{100 d t}\right)\left(\frac{V}{m}\right)+\left(\frac{S P_{\mathrm{CO}_{2}}\left(\frac{\left[\mathrm{CO}_{2}\right]}{100-0}\right) p}{m L}\right)$

where $r_{\mathrm{O}_{2}}$ and $r_{\mathrm{CO}_{2}}$ are the respiratory rates for $\mathrm{O}_{2}$ consumption and $\mathrm{CO}_{2}$ formation, respectively, both expressed as $\mathrm{mL} \mathrm{kg}^{-1} \mathrm{~h}^{-1}$; $\left[\mathrm{O}_{2}\right]$ and $\left[\mathrm{CO}_{2}\right]$ are the concentrations of $\mathrm{O}_{2}$ and $\mathrm{CO}_{2}$, respectively, expressed as \%; $L$ is the thickness of the film in $\mathrm{m}$; $S$ is the area of the bag $\left(\mathrm{m}^{2}\right) ; P_{\mathrm{O}_{2}}$ and $P_{\mathrm{CO}_{2}}$ are the permeability of the film for $\mathrm{O}_{2}$ and $\mathrm{CO}_{2}$, respectively $\left(\mathrm{mL} \mathrm{m}^{-2} \mathrm{~h}^{-1}\right.$ atm $\left.{ }^{-1}\right)$; $\mathrm{t}$ is the time in $\mathrm{h} ; V_{m}$ is the free volume in the bag $(\mathrm{mL})$; and $\mathrm{m}$ is the mass of product in the bag $(\mathrm{kg})$. Characteristics of the packaging: Length: $7.5 \mathrm{E}-5 \mathrm{~m}$, area: $4.2 \mathrm{E}-2 \mathrm{~m}^{2}, P_{O_{2}}: 83.3 \mathrm{~mL} \mathrm{~kg} \mathrm{k}^{-1} \mathrm{~atm}^{-1}$, and $P_{\mathrm{CO}_{2}}: 227.8 \mathrm{~mL} \mathrm{~kg}^{-1} \mathrm{~h}^{-1}$ atm ${ }^{-1}$ and $V_{m}: 755 \mathrm{~mL}$.

\subsection{Estimated respiration model parameters}

The respiration data obtained from Equations 3 and 4 are used to estimate the parameters of the enzyme kinetics. According to Fonseca, Oliveira and Brecht (2002), the role of $\mathrm{CO}_{2}$ in respiration is suggested to be mediated via the inhibition mechanism of Michaelis-Menten and is described by Equation 5 .

$r_{O_{2}}=\frac{V m_{O_{2}}\left[O_{2}\right]}{K m_{O_{2}}+\left[O_{2}\right]}$

where $V m_{O_{2}}$ is the maximum respiratory rate for $\mathrm{O}_{2}$ consumption $(\mathrm{mL} / \mathrm{kg} \mathrm{h})$ and $\mathrm{Km}_{\mathrm{O}_{2}}$ is the Michaelis-Menten constant for $\mathrm{O}_{2}$ consumption, expressed as $\% \mathrm{O}_{2}$.

Competitive, uncompetitive, and non-competitive inhibitions are described by Equations 6, 7, and 8, respectively.

$r_{\mathrm{O}_{2}}=\frac{V m_{\mathrm{O}_{2}}\left[\mathrm{O}_{2}\right]}{\left[\mathrm{O}_{2}\right]+\mathrm{Km}_{\mathrm{O}_{2}}\left(1+\frac{\left[\mathrm{CO}_{2}\right]}{\mathrm{Kmc}_{\mathrm{CO}_{2}}}\right)}$

$r_{\mathrm{O}_{2}}=\frac{V m_{\mathrm{O}_{2}}\left[\mathrm{O}_{2}\right]}{\mathrm{Km}_{\mathrm{O}_{2}}+\left[\mathrm{O}_{2}\right]\left(1+\frac{\left[\mathrm{CO}_{2}\right]}{\mathrm{Kmu}_{\mathrm{CO}_{2}}}\right)}$

$r_{\mathrm{O}_{2}}=\frac{V m_{\mathrm{O}_{2}}\left[\mathrm{O}_{2}\right]}{\mathrm{Km}_{\mathrm{O}_{2}}+\left[\mathrm{O}_{2}\right]\left(1+\frac{\left[\mathrm{CO}_{2}\right]}{\mathrm{Kmn}_{\mathrm{CO}}}\right)}$

where $\mathrm{Kmc}_{\mathrm{CO}_{2}}$ is the Michaelis-Menten constant for the competitive inhibition of $\mathrm{CO}_{2}$ on $\mathrm{O}_{2}$ consumption; $\mathrm{Kmu}_{\mathrm{CO}_{2}}$ is the Michaelis-Menten constant for the uncompetitive inhibition of
$\mathrm{CO}_{2}$ on $\mathrm{O}_{2}$ consumption; and $\mathrm{Kmn}_{\mathrm{CO}_{2}}$ is the Michaelis-Menten constant for the non-competitive inhibition of $\mathrm{CO}_{2}$ on $\mathrm{O}_{2}$ consumption. These three constants are expressed as $\% \mathrm{CO}_{2}$ (PEPPELENBOS; LEVEN, 1996).

\subsection{Respiratory quotient}

The ratio of the volume of $\mathrm{CO}_{2}$ produced to the volume of $\mathrm{O}_{2}$ consumed in the post-harvest respiratory process, known as the "Respiratory Quotient (RQ)", was calculated through Equation (9) (FONSECA; OLIVEIRA; BRECHT, 2002).

$R Q=0.727\left(\frac{r_{\mathrm{CO}_{2}}}{r_{\mathrm{O}_{2}}}\right)$

\subsection{Physical and chemical analysis}

Titratable acidity was determined according to standard methods as described in AOAC (ASSOCIATION..., 2003). The $\mathrm{pH}$ of the pulp of the fruits was determined using a digital pHmeter (330-SET). Total soluble solids were determined using an Atago refract meter (model PR 201), and the results were expressed as Brix. Reducing sugar values (glucose, fructose and sucrose) were determined according to the Miller method (MILLER, 1959). Weight loss was measured periodically using a scale, as described by Pereira et al. (2005). The analyses were performed on the $1^{\text {st }}, 3^{\text {rd }}, 5^{\text {th }}, 7^{\text {th }}, 9^{\text {th }}$, and $11^{\text {th }}$ days in triplicate.

\subsection{Statistical analysis}

The results were evaluated using the analysis of variance (ANOVA) using the Statistica 6.0 (Stafsoft Inc., USA) software, and the factors presenting significant difference $(\mathrm{p} \leq 0.05)$ were submitted to the means test (Tukey). The variables evaluated were: influences of storage period and temperature.

\section{Results and discussion}

\subsection{Gas analises}

\section{Gas exchange measurements}

Figures 1, 2, and 3 show the profiles of gas compositions of the fresh-cut apples stored in BOPP/LDPE bags at $2{ }^{\circ} \mathrm{C}, 5^{\circ} \mathrm{C}$, and $7{ }^{\circ} \mathrm{C}$, respectively. As expected, the results showed that in all cases the behavior followed the same tendency during the period analyzed, with a reduction in the oxygen content and an increase in the carbon dioxide content. For the samples stored at $2{ }^{\circ} \mathrm{C}$, the $\mathrm{O}_{2}$ content decreased from $21 \%$ ( $1^{\text {st }}$ hour) to $6.89 \%$ (190 hours), and the $\mathrm{CO}_{2}$ content increased from $0.02 \%$ to $7.98 \%$, in the same time period (Figure 1). Comparing the fitted values with the experimental data, the model was shown to be valid by the correlation coefficient $\left(\mathrm{R}^{2}=98.61\right)$. For samples at $5{ }^{\circ} \mathrm{C}$, the $\mathrm{O}_{2}$ content decreased from $21 \%$ ( $1^{\text {st }}$ hours) to $4.55 \%$ (190 hours), and the $\mathrm{CO}_{2}$ content increased from $0.02 \%$ to $10.45 \%$ (190 hours); the results are shown in Figure 2. For samples stored at $7{ }^{\circ} \mathrm{C}$, the $\mathrm{O}_{2}$ content decreased from $21 \%$ to $3.96 \%$, and the $\mathrm{CO}_{2}$ content increased from $0.02 \%$ to $12.61 \%$, 


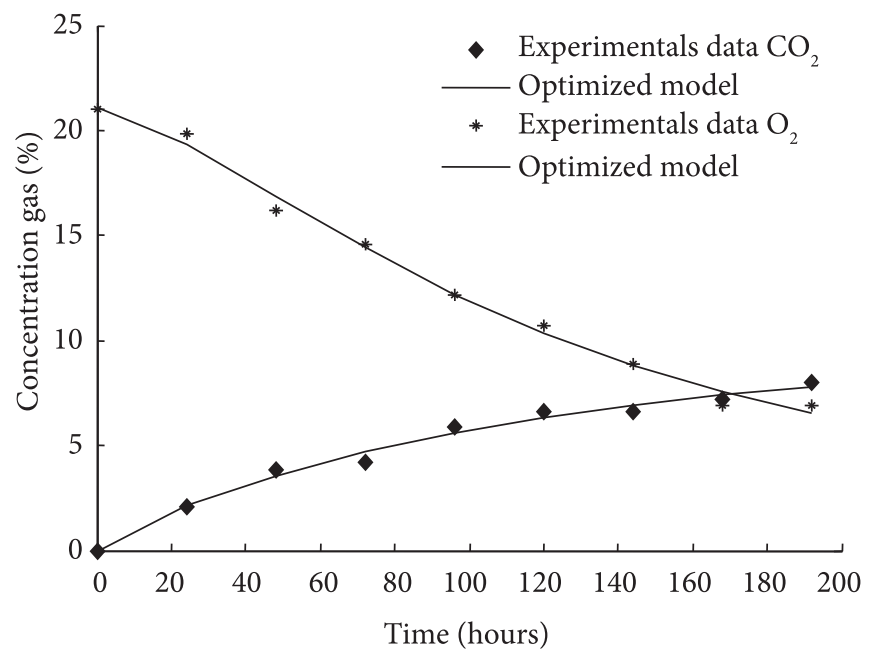

Figure 1. Evolution of $\mathrm{O}_{2}$ and $\mathrm{CO}_{2}$ of fresh-cut apples stored at $2{ }^{\circ} \mathrm{C}$ for 190 hours.

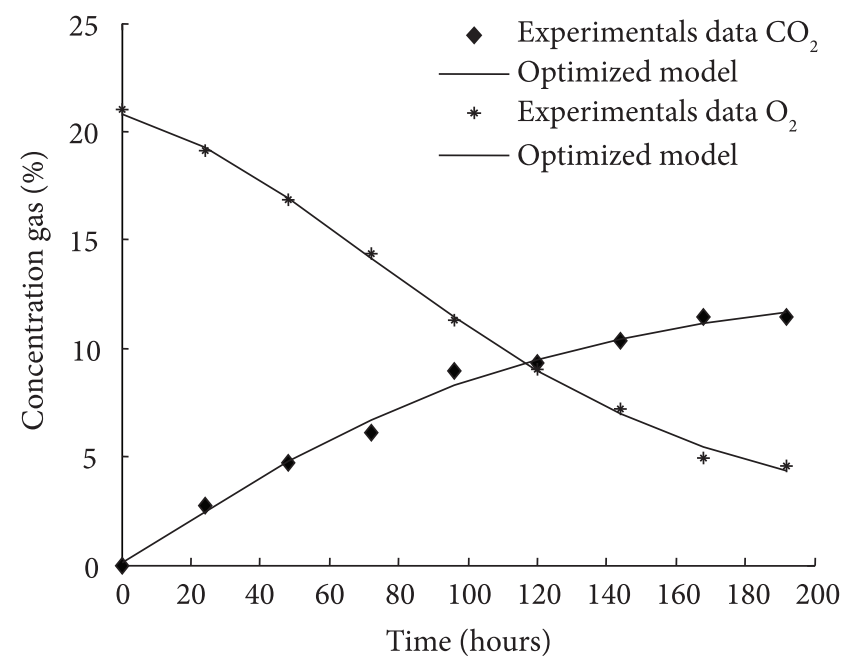

Figure 2. Evolution of $\mathrm{O}_{2}$ and $\mathrm{CO}_{2}$ of fresh-cut apples stored at $5{ }^{\circ} \mathrm{C}$ for 190 hours.

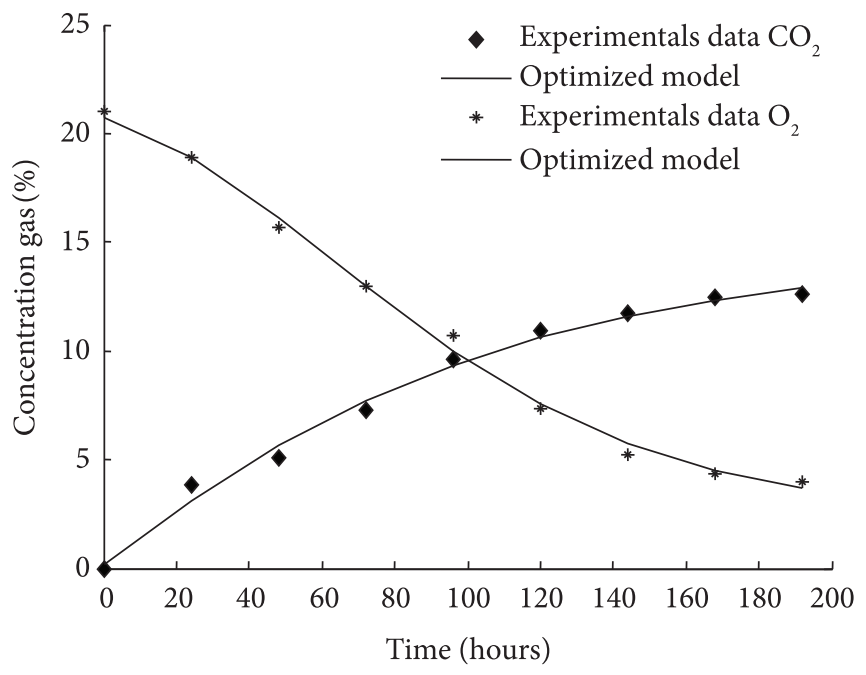

Figure 3. Evolution of $\mathrm{O}_{2}$ and $\mathrm{CO}_{2}$ of fresh-cut apples stored at $7{ }^{\circ} \mathrm{C}$ for 190 hours. as shown in Figure 3. At both temperatures of $5{ }^{\circ} \mathrm{C}$ and $7{ }^{\circ} \mathrm{C}$, the model showed a good fit to the experimental concentration data with $\mathrm{R}^{2}=98.70$ and $\mathrm{R}^{2}=98.21$, respectively. A significant difference was observed $(\mathrm{p} \leq 0.05)$ for $\mathrm{O}_{2}$ and $\mathrm{CO}_{2}$ concentrations between the temperature of $2{ }^{\circ} \mathrm{C}$ and the other temperatures during the entire storage period. Between the temperatures of $5^{\circ} \mathrm{C}$ and $7{ }^{\circ} \mathrm{C}$, a significant effect ( $\left.\mathrm{p} \leq 0.05\right)$ was observed up to 135 hours of storage. Results showed that the model based on enzyme kinetics should be used for apples stored under passive modified packaging using a permeable multilayer package of BOPP and LDPE. At the highest temperatures, $\mathrm{CO}_{2}$ content increased and $\mathrm{O}_{2}$ content decreased quickly and more greatly in the end of the storage period. This behavior is explained by the increase in the metabolic activity of fruits. These results are in agreement to those found by Rocculi et al. (2006), who studied the Golden Delicious variety of fresh-cut apples treated with anti-browning agents such as citric acid (1\%) and ascorbic acid $(1 \%)$ stored under passive atmosphere at $4^{\circ} \mathrm{C}$. According to Francis, Thomas, and O'Beirne (1999), fresh-cut vegetables are usually stored in semi-permeable packages since they continue respiring changing the gas atmosphere inside the package. Ideally, the $\mathrm{O}_{2}$ level will falls from $21 \%$ to $2-5 \%$, and the $\mathrm{CO}_{2}$ level will rises from $0.03 \%$ to $3-10 \%$. These gas levels, combined with refrigeration, slow down the respiration rate and thus extend shelf life. The concentration levels of $\mathrm{CO}_{2}$ and $\mathrm{O}_{2}$ obtained in this study are close to those recommended by these authors.

\section{Respiration rate of fresh-cut apples}

Figure 4 shows the data of the respiration rate obtained by the fresh-cut apples stored at $2{ }^{\circ} \mathrm{C}, 5^{\circ} \mathrm{C}$ and $7{ }^{\circ} \mathrm{C}$. The respiration rate was calculated from the experimental $\mathrm{O}_{2}$ and $\mathrm{CO}_{2}$ concentration data using Equations 3 and 4 . The respiration rate showed significant differences $(\mathrm{p} \leq 0.05)$ during the storage period, except after 144 hours of storage at $2{ }^{\circ} \mathrm{C}$ and $7{ }^{\circ} \mathrm{C}$. At $5^{\circ} \mathrm{C}$, a non- significant effect of storage period $(\mathrm{p} \leq 0.05)$ was observed after 168 hours. When the analysis was performed to evaluate only the temperature effect, a significant difference $(\mathrm{p} \leq 0.05)$ was observed between the temperature of $2{ }^{\circ} \mathrm{C}$ and the other temperatures. Temperature has been identified as the most important external factor which influences respiration. As

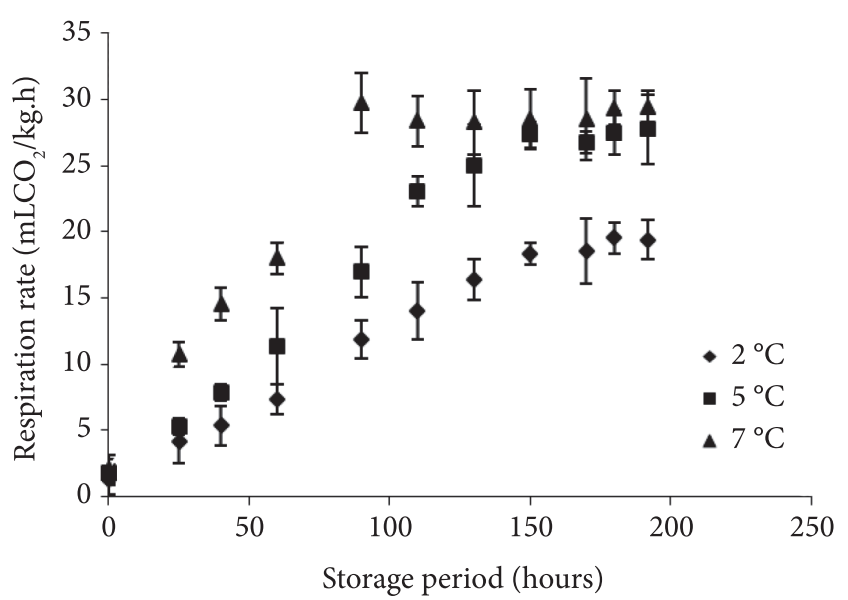

Figure 4. Respiration rate of fresh-cut apples stored at $2{ }^{\circ} \mathrm{C}, 5^{\circ} \mathrm{C}$, and $7^{\circ} \mathrm{C}$, for 190 hours. 
it can observed in this study, the highest respiration rate was at $7{ }^{\circ} \mathrm{C}$ and the lowest at $2{ }^{\circ} \mathrm{C}$. However, these respiration rate values did not affect the visual quality of the fresh-cut apples, probably because of the $\mathrm{O}_{2}$ level of $3.96 \%\left(\right.$ at $7{ }^{\circ} \mathrm{C}$ ) in the package headspace at the end of the storage period. Johnston et al. (2001) showed that the optimum storage temperature range for apples is from $0{ }^{\circ} \mathrm{C}$ to $3^{\circ} \mathrm{C}$, depending on the cultivar. However, the results obtained in this study show that the temperatures of $5{ }^{\circ} \mathrm{C}$ and $7{ }^{\circ} \mathrm{C}$, which are more commercially viable, can also be used for the storage of Gala apples. The results show that the low temperature and the type of packaging material prolonged the shelf-life of the product when compared to literature data. Peppelenbos and Leven (1996) showed that the storage of fresh-cut apples in an atmosphere rich in $\mathrm{CO}_{2}$ did not affect the respiration rate of the products since they had shelf-life of only four days. On the other hand, in this study, the apples were stored for eleven days in modified passive packaging only, i.e., without gas injection.

\section{Estimated respiration model parameters}

Table 1 shows the kinetic parameters obtained by regression analysis of the curves prepared from the experimental data of $\mathrm{O}_{2}$ consumption and $\mathrm{CO}_{2}$ production using the statistic software (6.0). Enzyme kinetics based on Michaelis-Menten was used to describe gaseous exchange between the product and the package for the fresh-cut apples studied. $\mathrm{V}_{\mathrm{mO}_{2}}, \mathrm{~K}_{\mathrm{mO}_{2}}$, and $\mathrm{K}_{\mathrm{mCO}_{2}}$ values for the models and temperatures had a significant difference at a $5 \%$ significance level using the $\mathrm{F}$ test. The $\mathrm{R}^{2}$ variance percentage values for models of different types of inhibition showed a clear effect of the $\mathrm{CO}_{2}$ on $\mathrm{O}_{2}$ consumption. For the model without inhibition, the $\mathrm{R}^{2}$ values are lower indicating less consistent

Table 1. Kinetics parameters of fresh-cut apples storage at $2{ }^{\circ} \mathrm{C}, 5^{\circ} \mathrm{C}$, and $7{ }^{\circ} \mathrm{C}$.

\begin{tabular}{|c|c|c|c|c|}
\hline & \multicolumn{4}{|c|}{ No inhibition } \\
\hline & $\mathrm{R}^{2}$ & $\mathrm{Vm}_{\mathrm{O}_{2}}(\mathrm{~mL} / \mathrm{kgh})$ & $\mathrm{Km}_{\mathrm{O}_{2}}(\%)$ & \\
\hline $2^{\circ} \mathrm{C}$ & 90.9 & 27.88 & 11.99 & \\
\hline $5^{\circ} \mathrm{C}$ & 89.6 & 23.13 & 10.82 & \\
\hline \multirow[t]{3}{*}{$7^{\circ} \mathrm{C}$} & 92.8 & 34.41 & 9.96 & \\
\hline & \multicolumn{4}{|c|}{ Competitive model (1) } \\
\hline & $\mathrm{R}^{2}$ & $\mathrm{Vm}_{\mathrm{O}_{2}}(\mathrm{~mL} / \mathrm{kgh})$ & $\mathrm{Km}_{\mathrm{O}_{2}}(\%)$ & $\mathrm{Kmc}_{\mathrm{CO}_{2}}(\%)$ \\
\hline $2^{\circ} \mathrm{C}$ & 98.7 & 25.57 & 9.99 & 32.11 \\
\hline $5^{\circ} \mathrm{C}$ & 99.4 & 29.23 & 10.52 & 37.85 \\
\hline \multirow[t]{3}{*}{$7^{\circ} \mathrm{C}$} & 97.9 & 33.72 & 12.34 & 41.22 \\
\hline & \multicolumn{4}{|c|}{ Uncompetitive model (2) } \\
\hline & $\mathrm{R}^{2}$ & $\mathrm{Vm}_{\mathrm{O}_{2}}(\mathrm{~mL} / \mathrm{kgh})$ & $\mathrm{Km}_{\mathrm{O}_{2}}(\%)$ & $\mathrm{Kminc}_{\mathrm{CO}_{2}}(\%)$ \\
\hline $2{ }^{\circ} \mathrm{C}$ & 90.9 & 28.45 & 11.87 & 29.56 \\
\hline $5^{\circ} \mathrm{C}$ & 89.6 & 26.64 & 11.76 & 26.41 \\
\hline \multirow[t]{3}{*}{$7^{\circ} \mathrm{C}$} & 92.8 & 36.22 & 10.94 & 23.32 \\
\hline & \multicolumn{4}{|c|}{ Non-competitive model (3) } \\
\hline & $\mathrm{R}^{2}$ & $\mathrm{Vm}_{\mathrm{O}_{2}}(\mathrm{~mL} / \mathrm{kgh})$ & $\mathrm{Km}_{\mathrm{O}_{2}}(\%)$ & $\mathrm{Kmnc}_{\mathrm{CO}_{2}}(\%)$ \\
\hline $2^{\circ} \mathrm{C}$ & 90.9 & 29.62 & 12.7 & 52.14 \\
\hline $5^{\circ} \mathrm{C}$ & 90.6 & 25.27 & 10.91 & 36.72 \\
\hline $7^{\circ} \mathrm{C}$ & 95.4 & 35.48 & 11.36 & 49.33 \\
\hline
\end{tabular}

results. High values of $\mathrm{R}^{2}$ are obtained for the three models. The competitive model generates the best results, especially at $5{ }^{\circ} \mathrm{C}\left(\mathrm{R}^{2}=99.4\right)$. Therefore, this is probably the predominant mechanism of inhibition in the process of respiration of freshcut apples, studied in this study. According to Peppelenbos and Leven (1996), kinetics parameters could be influenced by two factors: an increase in the $\mathrm{CO}_{2}$ concentration or a decrease in $\mathrm{O}_{2}$ concentrations. According to Fonseca, Oliveira and Brecht (2002), competitive inhibition occurs when the inhibitor $\left(\mathrm{CO}_{2}\right)$ and the substrate compete for the same active site of the enzyme. Thus, respiration rate is lower under high $\mathrm{CO}_{2}$ concentrations. Peppelenbos and Leven (1996) described the influence of $\mathrm{O}_{2}$ and $\mathrm{CO}_{2}$ on $\mathrm{O}_{2}$ consumption for cv. Golden delicious and Elstar apples. These authors compared the values of the percentage of variance $\left(\mathrm{R}^{2}\right)$ of the model with and without inhibition of $\mathrm{CO}_{2}$ for the two varieties. According to these authors, the $\mathrm{CO}_{2}$ concentrations did not influence the $\mathrm{O}_{2}$ consumption rates or any of the three types of inhibition when compared to the model without inhibition and showed significant difference in variance values $\left(R^{2}\right)$. Different behavior was observed in this study since gas concentration influenced the respiration rate. This difference may be caused by factors such as variety and growing conditions, which cause differences in the composition of the fruit.

\section{Respiratory Quotient (RQ)}

RQ results of fresh-cut apples obtained from Equation 9 were: RQ average at $2{ }^{\circ} \mathrm{C}, 1.09$; at $5{ }^{\circ} \mathrm{C}, 1.48$; and at $7^{\circ} \mathrm{C}, 1.90$. According to Fonseca, Oliveira and Brecht (2002), if the RQ is equal to 1.0, the metabolic substrates are carbohydrates. If the substrate is lipid, the RQ is always lower than unity. If the substrate is an acid, the RQ is higher than unity. $\mathrm{O}_{2}$ consumption and $\mathrm{CO}_{2}$ production rate values were used to evaluate the factors affecting the RQ of fresh-cut apples evaluated in this study during the storage period. The RQ values above 1 obtained showed that the predominant substrate is an organic acid. Normal RQ values in the literature are reported as ranging from 0.7 to 1.3 (KADER, 1986; BEAUDRY et al., 1992). This range agrees with the results obtained in this study for fresh-cut apples. Renault et al. (1994) found RQ values of 1.0 for strawberries, and according to these authors, this result indicates high glycosides concentration. Beaudry et al. (1992) showed RQ values of 1.3 for blueberries because of their high content of citric and sugars. According to Saquet and Streif (2002), apples metabolize mostly organic acids during storage until their content is decreased by half. After that, the carbohydrates may be included in this process.

\subsection{Physicochemical characterization}

Titratable acidity, pH, total soluble solids, reducing sugars, and water loss

Table 2 shows the results of titratable acidity, $\mathrm{pH}$, total soluble solids, reducing sugars, and water loss.

A decrease in titratable acidity and a non-significant effect $(p \geq 0.05)$ were observed during the storage period between the temperatures studied (Table 2). However, higher temperatures 
Table 2. Titratable acidity (\% ácido málico), $\mathrm{pH}$, total soluble solids ( ${ }^{\circ}$ Brix), reducing sugars $(\mathrm{mg} / \mathrm{mL})$, and weight loss $(\%)$ of fresh-cut apples stored at $2^{\circ} \mathrm{C}, 5^{\circ} \mathrm{C}$, and $7{ }^{\circ} \mathrm{C}$, during 11 days.

\begin{tabular}{|c|c|c|c|c|c|c|}
\hline & 1 & 3 & 5 & 7 & 9 & 11 \\
\hline \multicolumn{7}{|c|}{ Titratable acidity } \\
\hline $2^{\circ} \mathrm{C}$ & $1.36^{\mathrm{aA}}$ & $1.15^{\mathrm{aA}}$ & $1.15^{\mathrm{aA}}$ & $0.93^{\mathrm{aA}}$ & $0.97^{\mathrm{aA}}$ & $0.95^{\mathrm{aA}}$ \\
\hline $5^{\circ} \mathrm{C}$ & $1.58^{\mathrm{aA}}$ & $1.38^{\mathrm{aA}}$ & $1.18^{\mathrm{aA}}$ & $1.57^{\mathrm{aA}}$ & $1.11^{\mathrm{aA}}$ & $1.07^{\mathrm{aA}}$ \\
\hline $7^{\circ} \mathrm{C}$ & $1.47^{\mathrm{aA}}$ & $1.04^{\mathrm{aA}}$ & $0.91^{\mathrm{aA}}$ & $0.92^{\mathrm{aA}}$ & $1.02^{\mathrm{aA}}$ & $0.93^{\mathrm{aA}}$ \\
\hline \multicolumn{7}{|c|}{$\mathrm{pH}$} \\
\hline $2^{\circ} \mathrm{C}$ & $3.42^{\mathrm{aA}}$ & $3.61^{\mathrm{aA}}$ & $3.53^{\mathrm{aA}}$ & $3.57^{\mathrm{aA}}$ & $3.61^{\mathrm{aA}}$ & $3.58^{\mathrm{aA}}$ \\
\hline $5^{\circ} \mathrm{C}$ & $3.39^{\mathrm{aA}}$ & $3.42^{\mathrm{aA}}$ & $3.42^{\mathrm{aA}}$ & $3.55^{\mathrm{aA}}$ & $3.55^{\mathrm{aA}}$ & $3.7^{\mathrm{aA}}$ \\
\hline $7^{\circ} \mathrm{C}$ & $3.45^{\mathrm{aA}}$ & $3.56^{\mathrm{aA}}$ & $3.58^{\mathrm{aA}}$ & $3.65^{\mathrm{aA}}$ & $3.62^{\mathrm{aA}}$ & $3.75^{\mathrm{aA}}$ \\
\hline \multicolumn{7}{|c|}{ Total soluble solids } \\
\hline $2^{\circ} \mathrm{C}$ & $12.04^{\mathrm{aA}}$ & $11.9^{\mathrm{aA}}$ & $11.92^{\mathrm{aA}}$ & $12.3^{\mathrm{aA}}$ & $12.5^{\mathrm{aA}}$ & $12.43^{\mathrm{aA}}$ \\
\hline $5^{\circ} \mathrm{C}$ & $12.35^{\mathrm{aA}}$ & $11.73^{\mathrm{aA}}$ & $11.72^{\mathrm{aA}}$ & $12.28^{\mathrm{aA}}$ & $11.61^{\mathrm{abA}}$ & $11.44^{\mathrm{bA}}$ \\
\hline $7^{\circ} \mathrm{C}$ & $12.80^{\mathrm{aA}}$ & $12.45^{\mathrm{aA}}$ & $11.83^{\mathrm{aA}}$ & $11.47^{\mathrm{aA}}$ & $10.91^{\mathrm{bA}}$ & $10.26^{\mathrm{cA}}$ \\
\hline \multicolumn{7}{|c|}{ Reducing sugars } \\
\hline $2^{\circ} \mathrm{C}$ & $55.38^{\mathrm{aA}}$ & $54.67^{\mathrm{aA}}$ & $59.31^{\mathrm{aA}}$ & $62.02^{\mathrm{aA}}$ & $54.99^{\mathrm{aA}}$ & $56.91^{\mathrm{aA}}$ \\
\hline $5^{\circ} \mathrm{C}$ & $66.14^{\mathrm{bA}}$ & $66.33^{\mathrm{aA}}$ & $65.89^{\mathrm{aA}}$ & $66.99^{\mathrm{aA}}$ & $68.59^{\mathrm{bA}}$ & $63.58^{\mathrm{aA}}$ \\
\hline $7^{\circ} \mathrm{C}$ & $64.34^{\mathrm{bA}}$ & $57.21^{\mathrm{aAB}}$ & $58.82^{\mathrm{aAB}}$ & $58.07^{\mathrm{AB}}$ & $55.65^{\mathrm{aB}}$ & $52.14^{\mathrm{bB}}$ \\
\hline \multicolumn{7}{|c|}{ Weight loss (\%) } \\
\hline $2^{\circ} \mathrm{C}$ & $0^{\mathrm{aA}}$ & $0.042^{\mathrm{aA}}$ & $0.049^{\mathrm{aA}}$ & $0.059^{\mathrm{aA}}$ & $0.082^{\mathrm{aA}}$ & $0.086^{\mathrm{aA}}$ \\
\hline $5^{\circ} \mathrm{C}$ & $0^{\mathrm{aA}}$ & $0.017^{\mathrm{aA}}$ & $0.057^{\mathrm{aAB}}$ & $0.103^{\mathrm{aAB}}$ & $0.132^{\mathrm{aB}}$ & $0.162^{\mathrm{aB}}$ \\
\hline $7^{\circ} \mathrm{C}$ & $0^{\mathrm{aA}}$ & $0.026^{\mathrm{aA}}$ & $0.058^{\mathrm{aAB}}$ & $0.162^{\mathrm{aABC}}$ & $0.266^{\mathrm{aBC}}$ & $0.303^{\mathrm{aC}}$ \\
\hline
\end{tabular}

Same lowercase letters in columns and same capitals letters in rows indicate nonsignificant difference at $5 \%$ level of probability according to the Tukey test.

showed a pronounced decline in titratable acidity. This behavior may be linked to the fact that higher temperatures increase the respiration rate, and therefore there is greater degradation of organic acids. Similar results were showed by Olivas, Mattinson, and Barbosa-Cánovas (2007) for cv. Gala apples stored at $5{ }^{\circ} \mathrm{C}$ for nine days. Rocha and Morais (2003) found acidity values ranging from 0.52 to 0.29 (\% malic acid) with significant difference $(\mathrm{p} \leq 0.05)$ between those of fresh-cut Jonagored apples stored at $4^{\circ} \mathrm{C}$ for 10 days. Lower values were observed when compared to the results obtained in this study. This difference may be caused by factors such as variety and growing conditions, which cause differences in the composition of the fruit. According to Sadler and Murphy (1998), in both post-harvest and storage periods, the concentration of organic acids decreases due to their use as a substrate in the respiration or their transformation into sugars. Comparing these results to the respiratory quotient (RQ) and the $\mathrm{pH}$, it can be observed that organic acids are the substrates consumed during respiration.

A non-significant increase in $\mathrm{pH}(\mathrm{p} \geq 0.05)$ (Table 2) was observed during the storage period between the temperatures tested. The greater increase in $\mathrm{pH}$ was observed at temperatures of $5^{\circ} \mathrm{C}$ and $7{ }^{\circ} \mathrm{C}$. Higher $\mathrm{pH}$ values were obtained probably due to the metabolic processes of the fruit. This behavior is consistent with the results obtained for titratable acidity. Similar results ( $\mathrm{pH}$ values of 3.71 to 3.78 ) were found by Rocculi, Romani and Rosa (2004) for cv. Golden Delicious apples immersed in solutions of $0.5 \%$ Citric Acid, $0.5 \%$ Ascorbic acid, and 0.5\% Calcium Chloride and stored at $4{ }^{\circ} \mathrm{C}$ for 12 days. Rocha and Morais (2003) observed a slight but not significant increase in $\mathrm{pH}$ values (3.5-3.7) and related this increase to the small decrease in total acidity attributing the result to the effect of the buffer on the apple tissues.

Total soluble solids decreased during the storage period, but a non-significant effect $(\mathrm{p} \geq 0.05)$ was observed (Table 2$)$. At $2{ }^{\circ} \mathrm{C}$, the soluble solid content ranged from 12.04 to $12.43^{\circ} \mathrm{Brix}$. At $5{ }^{\circ} \mathrm{C}$ and $7{ }^{\circ} \mathrm{C}$, these values ranged from $12.35^{\circ}$ Brix to $11.44^{\circ}$ Brix and from $12.80^{\circ}$ Brix to $10.26^{\circ}$ Brix, respectively. The temperature effect analyzed showed significant difference $(p \leq 0.05)$ between the three temperatures evaluated after the ninth day of storage. For higher temperatures, there was a greater decrease in the soluble solid values, fact that can be attributed to the increase in the respiratory rate as a function of the temperature. Olivas, Mattinson and Barbosa-Cánovas (2007) found values that ranged from 14.6 to $12.8^{\circ} \mathrm{Brix}$ for $\mathrm{cv}$. Gala apples coated with alginate and stored at $5{ }^{\circ} \mathrm{C}$ for nine days. These results are similar to those found in this study. Also, similar results were obtained by Fontes et al. (2008) for cv. Gala apples treated with a preservative solution containing ascorbic acid ( $1 \%)$, citric acid $(0.5 \%)$, calcium chloride $(0.25 \%)$, and sodium chloride $(0.7 \%)$ stored at $2{ }^{\circ} \mathrm{C}$ for 13 days.

Reducing sugars content ranged from 55.38 to 56.91 at $2{ }^{\circ} \mathrm{C}$, a small but not significant increase was observed $(p \geq 0.05)$ during storage (Table 2). For the temperatures of $5{ }^{\circ} \mathrm{C}$ and $7^{\circ} \mathrm{C}$, the values ranged from 66.14 to 63.58 and 64.34 to 52.14 , respectively. At $7{ }^{\circ} \mathrm{C}$, a pronounced decline was observed, and there was a significant difference $(\mathrm{p} \leq 0.05)$ between the first and the subsequent days of storage. This result indicates the influence of temperature on reducing sugars. Moreover, the analysis between the different temperatures evaluated showed a significant difference ( $\mathrm{p} \leq 0.05)$ only on the first day of storage. These results may be due to the difference in the composition of the sugars of the raw materials. Fruits of the same farm, even when grown and harvested at the same time, may have a different composition. Similar results were obtained by Rocha and Morais (2003) for fresh-cut apples stored at $4{ }^{\circ} \mathrm{C}$ for ten days and by Soliva-Fortuni and Martín-Belloso (2003) for pears stored at $4{ }^{\circ} \mathrm{C}$ for 14 days. According to Buta and Moline (1999), during post-harvest and storage, organic acid content decreases due to its use as a substrate in the respiration or transformation into sugars. In general, there is an increase in sugar content after harvesting and a decrease in the end of the storage period due to the use of sugar in fruit respiration as an energy source. However, in this study, a significant reduction in the reducing sugar content was observed during storage at temperatures of $5^{\circ} \mathrm{C}$ and $7^{\circ} \mathrm{C}$, which may be related to the fact that whole apples are stored for long periods, and therefore the results only show only the use of sugar as energy source.

The maximum water loss during the storage period was $0.086 \%, 0.16 \%$, and $0.303 \%$ at $2{ }^{\circ} \mathrm{C}, 5^{\circ} \mathrm{C}$ and $7{ }^{\circ} \mathrm{C}$, respectively (Table 2). A significant effect ( $\mathrm{p} \leq 0.05$ ) was observed during the storage period for the samples stored at $5{ }^{\circ} \mathrm{C}$ and $7^{\circ} \mathrm{C}$. When the effect of temperature was analyzed, the results showed significant difference $(\mathrm{p} \leq 0.05)$ in water loss between the temperatures evaluated on the last days of storage. The results obtained in this study indicate the influence of temperature on the increase of weight loss. Similar results were obtained by Rocha and Morais (2003) for apples stored at $4{ }^{\circ} \mathrm{C}$ for ten days (0.22\%). Perez- 
Gago, Serra and Del Rio (2006) found high weight loss value (3\%) for apples stored at $4{ }^{\circ} \mathrm{C}$ for 13 days. The samples were immersed in a $0.5 \%$ and $1.0 \%$ acid ascorbic solution. Rocculi, Romani and Rosa (2004) evaluated cv. Golden Delicious apples immersed in solutions of $0.5 \%$ Citric Acid, $0.5 \%$ Ascorbic acid, and $0.5 \%$ Calcium Chloride and stored at $4{ }^{\circ} \mathrm{C}$ for 12 days, and the maximum water loss obtained during the storage period was $0.36 \%$ for all samples studied. These results are similar to those found in this study at $7{ }^{\circ} \mathrm{C}$. According to Kang and Lee (1998), a 5\% weight loss results in quantitative and qualitative losses of firmness. The comparison of results obtained in this study with that proposed by Kang and Lee, it seems that the packaging used to store fresh-cut apples proved to be a good barrier to water vapor. It prevented excessive water loss and preserved the appearance and texture of the apples evaluated.

\section{Conclusion}

The gas evolution inside the package showed increases in $\mathrm{CO}_{2}$ concentrations and decreases in $\mathrm{O}_{2}$ concentrations, as expected. The mathematical model used showed good fitting to the experimental data, as shown by the correlation coefficient values. The highest respiration rate was found at $7{ }^{\circ} \mathrm{C}$, and the lowest at $2{ }^{\circ} \mathrm{C}$. Temperature was identified as the most important external factor which influences respiration. Inhibition models showed a clear effect of the $\mathrm{CO}_{2}$ on $\mathrm{O}_{2}$ consumption, suggesting that competitive inhibition probably occurred. The physicochemical analysis showed that fresh-cut apples stored at $2{ }^{\circ} \mathrm{C}, 5^{\circ} \mathrm{C}$ and $7{ }^{\circ} \mathrm{C}$ for 11 days were suitable for consumption.

\section{Acknowledgements}

The authors are grateful for the financial support provided by Capes - Brazilian research supporting foundation and FAPESC: Scientific and Technological Research Support Foundation of Santa Catarina

\section{References}

ALBANESE, D.; CINQUANTA, L.; DI MATTEO, M. Effects of an innovative dipping treatment on the cold storage of minimally processed Annurca apples. Food Chemistry, v. 105, p. 1054-1060. 2007. http://dx.doi.org/10.1016/j.foodchem.2007.05.009

ASSOCIATION OF OFFICIAL ANALYTICAL CHEMISTS - AOAC. Official methods of analysis of AOAC International. 17th ed. Washington: AOAC, 2003.

BEAUDRY, R. M. et al. Modified atmosphere packaging $\mathrm{O}_{2}$ and $\mathrm{CO}_{2}$. Journal American Society of Horticultural Science, v. 117, n. 3 , p. 436-441, 1992.

BUTA, J. G.; MOLINE, H. E. Extending storage life of fresh-cut apples using natural products and their derivatives. Journal Agriculture Food Chemical, v. 47, n. 1, p. 1-6, 1999. PMid:10563838. http:// dx.doi.org/10.1021/jf980712x

CHITARrA, M. I. F.; CHITARRA, A. B. Pós-colheita de Frutas e Hortaliças: fisiologia e manuseio. 2. ed. Lavras: UFLA, 2005. 783 p.

FONSECA, S. C.; OLIVEIRA, F. A. R.; BRECHT, J. K. Modelling respiration rate of fresh fruits and vegetables for modified atmosphere packages: a review. Journal of Food Engineering, v. 52, n. 2, p. 99-119, 2002. http://dx.doi.org/10.1016/S02608774(01)00106-6
FONTES, L. C. B. et al. Conservação de maçã minimamente processada com o uso de películas comestíveis. Ciência Tecnologia Alimentos, v. 28, n. 4, p. 1-9, 2008. http://dx.doi.org/10.1590/S010120612008000400017

FRANCIS, G. A.; THOMAS, C.; O'BEIRNE, D. The microbiological safety of minimally processed vegetables. International Journal Food Science Technology, v. 34, p. 1-22, 1999. http://dx.doi. org/10.1046/j.1365-2621.1999.00253.x

JAYAS, D. S.; JEYAMKONDAN, S. Modified atmosphere storage of grains meats fruits and vegetables. Biosystems Engineering, v. 82, p. 235-251, 2002. http://dx.doi.org/10.1006/bioe.2002.0080

JOHNSTON, J. W. et al. Temperature induces differential softening responses in apple cultivars. Postharvest Biology Technology, v. 23 , n. 1, p. 185-196, 2001. http://dx.doi.org/10.1016/S09255214(01)00127-2

KADER, A. A. Biochemical and physiological basis for effects of controlled and modified atmospheres on fruits and vegetables. Journal Food Technology, v. 40, n. 5, p. 99-104, 1986.

KANG, J. S.; LEE, D. S. A Kinetic Model for transpiration of fresh produce in a controlled atmosphere. Journal of Food Engineering, v. 35 , n. 1, p. $65-73,1998$. http://dx.doi.org/10.1016/S02608774(98)00009-0

LEE, D. S.; SONG, Y.; YAM, K. L. Application of an enzyme kinetics based on respiration model to permeable system experiment of fresh produce. Journal of Food Engineering, v. 27, n. 3, p. 297-310. 1996. http://dx.doi.org/10.1016/0260-8774(95)00012-7

MARTÍNEZ-FERRER, M. et al. Modified atmosphere packaging of minimally processed mango and pineapple fruits. Journal of Food Science, v. 67, p. 3365-3371. 2002. http://dx.doi. org/10.1111/j.1365-2621.2002.tb09592.x

MILLER, G. L. Use of de dinitrosalicylic acid reagent for determination of reducing sugar. Analytical Chemical, v. 31, n. 3, p. 426-428. 1959. http://dx.doi.org/10.1021/ac60147a030

OLIVAS, G. I.; MATTINSON, D. S.; BARBOSA-CÁNOVAS, G. V. Alginate coatings of minimally processed 'Gala' apples. Postharvest Biology Technology, v. 45, n. 1, p. 89-96, 2007. http://dx.doi. org/10.1016/j.postharvbio.2006.11.018

OLUSOLA, L. Fresh-Cut Fruits and Vegetables: Science. Technology and Market, CRC Press, 2002.

PAREIRA, L. M. et al. Influence of modified atmosphere packaging and osmotic dehydration on the quality maintenance of minimally processed guavas. Journal of Food Science, v. 69, p. 172-177, 2004.

PEPPELENBOS, H. W.; LEVEN, J. V. Evaluation of four types of inhibition for modeling the influence of carbon dioxide on oxygen consumption of fruits and vegetables. Postharvest Biology and Technology, v. 7, n. 1, p. 27-40, 1996. http://dx.doi. org/10.1016/0925-5214(96)80995-1

PEREIRA, T. et al. Características físicas equímicas de goiaba cv Cortibel (Psidium guajava) estocadas sob refrigeração em filmes X-tend. Revista Alimentos e Nutrição, v. 16, n. 1, p. 11-16, 2005.

PEREZ-GAGO, M. B.; SERRA, M.; DEL RIO, M. A. Color change of fresh-cut applescoatedwith whey protein concentrate-based edible coatings. Postharvest Biology Technology, v. 39, n. 1, p. 84-92, 2006. http://dx.doi.org/10.1016/j.postharvbio.2005.08.002

RENAULT, P. et al. Gas exchange in modified atmosphere packaging. 2: Experimental results with strawberries. International Journal Food Science Technology, v. 29, n. 4, p. 379-394, 1994. http://dx.doi. org/10.1111/j.1365-2621.1994.tb02080.x

ROCHA, A. M. C. N.; MORAIS, A. M. M. B. Shelf life of minimally processed Apple (cv. Jonared) determined by colour changes. Food 
Control, v. 14, n. 1, p. 13-20, 2003. http://dx.doi.org/10.1016/S09567135(02)00046-4

ROCHA, A. M. C. N.; BARREIRO, M. G.; MORAIS, A. M. M. B. Modified atmosphere package for apple 'Bravo de Esmolfe'. Food Control, v. 15, p. 61-64. 2004. http://dx.doi.org/10.1016/S09567135(03)00015-X

ROCCULI, P. et al. Use of a simple mathematical model to evaluate dipping and MAP effects on aerobic respiration of minimally processed apples. Journal of Food Engineering, v. 76, n. 3, p. 334-340, 2006. http://dx.doi.org/10.1016/j.jfoodeng.2005.05.034

ROCCULI, P.; ROMANI, S.; ROSA, M.D. Evaluation of physicochemical parameters of minimally processed apples packed in non-conventional modified atmosphere. Food Research International, v. 37, n. 4, p. 329-335, 2004. http://dx.doi. org/10.1016/j.foodres.2004.01.006

SALTVEIT, M. E. Fresh-cut vegetables. In: BARTZ, J. A.; BRECHT, J. K. (Eds.). Postharvest physiology and pathology of vegetables. New York: Marcel Dekker, 2003. cap. 22, p. 691-712.

SADLER, G. D.; MURPHY, P. A. pH and titratable acidity. In: NIELSEN, S. (Ed.). Food Analysis, 2. Gaithersburg: Aspen Publishers, Inc., 1998. p. 101-116.
SAQUET, A. A.; STREIF, J. R. Respiração e produção de etileno de maçãs armazenadas em diversas concentrações de oxigênio. Revista Brasileira Agrociência, v. 8, n. 1, p. 71-75, 2002.

SOLIVA-FORTUNY, R. C.; BELLOSO, O. M. Microbiological and Biochemical Changes in Minimally Processed Fresh-cut Conference Pears. European Food Research Technology, v. 217, n. 1, p. 4-9, 2003. http://dx.doi.org/10.1007/s00217-003-0701-8

SOLIVA-FORTUNY, R. C.; ELEZ-MARTINEZ, P.; MARTINBELLESO, O. Microbiological and biochemical stability of fresh cut apples preserved by modified atmosphere packaging. Innovative Food Science and Emerging Technologies, v. 5, p. 215-224. 2004. http://dx.doi.org/10.1016/j.ifset.2003.11.004

SOLIVA-FORTUNY, R. et al. Browning, polyphenol oxidase activity and headspace gas composition during storage of minimally processed pears using modified atmosphere packaging. Journal Science Food Agriculture, v. 82, p. 1490-496, 2002. http://dx.doi. org/10.1002/jsfa.1209

WU, Z. S.; ZHANG, M.; WANG, S. Effects of high pressure argon treatments on the quality of fresh-cut apples at cold storage. Food Control, v. 23, n. 1, p. 120-127, 2012 http://dx.doi.org/10.1016/j. foodcont.2011.06.021

YANG, C. C.; CHINNAN, M. S. Modelling the effect of $\mathrm{O}_{2}$ and $\mathrm{CO}_{2}$ on respiration and quality of stored tomatoes. American Society of Agricultural Biological Engineers, v. 31, n. 3, p. 920-925, 1988. 